\title{
Buyer-Supplier Relationships and the Resource- Advantage Perspective: An Illustrative Example of Relational and Transactional Drivers of Competitiveness
}

\author{
Raškovic Matevそ̌, Makovec Brenčič Maja
}

\begin{abstract}
The purpose of this paper is to illustrate how the so called resource-advantage perspective can be used to determine the importance of specific relational and transactional dimensions of buyer-supplier relationships in driving relationship competitiveness within a transnational company (TNC). The main objective of our research was to analyze which and how much specific relational and/or transactional dimensions of buyer-supplier relationships affect TNC buyer-supplier relationship competitiveness. Based on an illustrative empirical example, we tested a simple variance-based reflective Structural Equation Model (SEM) with main effects based on a sample of 130 TNC buyer-supplier relationships. Our results show that buyer-supplier relationship competitiveness is mostly driven by interpersonal trust and joint problem solving (both relational determinants), as well as by two kinds of transaction-specific investments (TSIs), namely investments into people and physical assets. In terms of theoretical implications, our results show that the resource-advantage theory of competition can link both the relationship marketing and the transaction cost economics perspective of buyer-supplier relationship management. We further provide some managerial recommendations for more effective management of TNC buyer-supplier relationships in terms of leveraging competitiveness.
\end{abstract}

Key words: relationship-based view, resource-advantage theory of competition, transnational companies, buyer-supplier relationships, competitiveness

\section{INTRODUCTION}

Within the marketing literature, Dyer \& Singh (1998), Kaufman, Wood \& Theyel (2000), and Nishiguchi \& Anderson (1995) explicitly point to buyer-supplier relationships as an important source of a company's competitive advantage. Thus, if a company's competitive advantage is based on its supply relationships (Gaddé \& Håkansson, 2001; Nagurney, 2010), then the development and management of these relationships should be seen as an important source of organizational competitive advantage; which in turn provides the foundation for overall organizational competitiveness (Mráček \& Mucha, 2011; cf. Zich, 2010). This is believed to be especially true for transnational companies (TNCs), which Hymer (1979) has described as both "the dominant organizational form of modern capitalism" (p. 1) and the most widespread organizational "method of organizing international exchange".

The increased specialization and outsourcing activities employed by TNCs today have made buyer-supplier relationships a focal point of organizational competitiveness, performance and long-term success (Veludo, Macbeth and Purchase, 2006). This is because "the competitiveness and 
profit-generating capacity of the individual firm is highly dependent on its ability to bandle the supply side" (Gaddé \& Håkansson, 2001, p. 4), leading to supply chains and networks of supply relationships being thought of as the "backbones of economic activities in the modern world" (Nagurney, 2010, p. 200). In this regard, "global supply chain management [and the management of supply relationships] can be viewed as a primary driver of both customer and shareholder value" (Griffith \& Myers, 2005, p. 254). Such a valuedriving perspective of buyer-supplier relationships has connected the organizational competitiveness literature and the relationship marketing literature to help explore how inter-organizational relationships and specific relational determinants of these relationships present important levers of organizational competitiveness. Thus, we can observe a sort of relationship paradigm "spillover" into the field of transaction economics-dominated organizational competitiveness literature, which provides an interesting substantive platform for future research of relationshipbased organizational competitiveness.

The purpose of this paper is to illustrate how Hunt \& Morgan's (1995) resource-advantage theory of competition can be used to link the importance of specific relational and transactional dimensions of buyer-supplier relationships in driving relationship competitiveness within a TNC context. This was done based on an illustrative case, where we tested a simple variance-based reflective structural equation model (SEM) of main effects from a sample of 130 TNC buyer-supplier relationships. Our approach builds on the growing perspective of analyzing TNCs as spaces of social relationships (Morgan, Kristensen \& Whitley, 2003) by further taking Hunt \& Morgan’s $(1995,1996,1997)$ resource-advantage theory of competition as a good substantive theoretical framework which allows us to compare and integrate both the relational and transactional determinants of organizational competitiveness. In doing so, our main objective was to analyze which and how much specific relational and/or transactional dimensions of buyer-supplier relationships impact TNC buyer-supplier relationship competitiveness in order to see if the relational and transaction perspectives to buyer-supplier relationship management should be understood as alternative or complementary perspectives in the context of organizational competitiveness?

\section{THEORETICAL FRAMEWORK}

\subsection{The resource-advantage perspective of TNC competitiveness}

In addressing the issue of TNC competitive advantage, we are employing Barney's (1991) resource-based definition of competitive advantage which emphasizes the implementation of "a value creating strategy not simultaneously being implemented by any current or potential competitors" (Barney, 1991, p. 102). While being quite simple, Barney's definition connects well to Morgan \& Hunt's (1994) relationship marketing perspective - which emphasizes the importance of long-term and value-adding relationships, which have a superior impact on performance and/or competitiveness outcomes (Morgan \& Hunt, 1994) - as well as to their subsequent comparative advantage and later resourceadvantage theory of competition (Hunt \& Morgan, 1995, 1996, 1997). For example, Makovec Brenčič (2000, pp. 95-108) gave a comprehensive historical and evolutionary overview of how the resource-based view of the firm - started by Penrose (1959/1995) - provided the basis for the development of Hunt \& Morgan's (1995) comparative advantage theory. This theory focused on a dynamic disequilibrium perspective of competition and led to the development of the resource-advantage theory of competition (Hunt, 1995; Hunt \& Morgan, 1996; Hunt \& Morgan, 1997). This theory established unique organizational resources as the bedrock of organizational competitiveness. 
In their work "The Comparative Advantage Theory of Competition" in the Journal of Marketing Hunt \& Morgan (1995, p. 1) focused on developing "a new theory of competition - one that has significant advantages over neoclassical theory". They achieved this by drawing not only on the resource-based view of the firm, but also on (Hunt \& Morgan, 1995, p. 1):

1. "The works on competitive advantage from marketing and industrial economics" (cf. Porter, 1980; Porter, 1985; Day \& Wensley, 1988; Porter, 1990; Bharadwaj, Varadarajan \& Fahy, 1993; Day \& Nedungadi, 1994);

2. "The theory of competitive rationality from Austrian economics" (cf. Dickson, 1992); and

3. "The theory of differential advantage from marketing and economics" (cf. Alderson, 1957; Clark, 1961; Alderson, 1965).

By addressing each assumption of neoclassic market theory (and its implications for competition) through the process of the "epistemology of scientific realism" (Hunt \& Morgan, 1995, p. 5; Hunt, 1991) they outlined a dynamic and disequilibrium model of competition which addressed cross-industry and intra-industry heterogeneity; the heterogeneity of consumer behavior and demand; the asymmetry of information; constrained self-interest as human motivation, the focus on superior financial performance (vis-à-vis profit maximization as a goal of the firm); the tangibility, intangibility, as well as heterogeneity and imperfect mobility of resources.

Within such a setting, competition was based on comparative advantage, not simply quantity adjustment, as assumed by neoclassical theory. While Hunt \& Morgan's (1995, p. 13) intention was to establish marketing as not being a "nefarious market imperfection creator [... but being ...] presumably pro-competitive" - it really emphasized the importance of resources as the key foundation of comparative advantage, and which "yield a market place position of competitive advantage and, thereby, superior financial performance". This led to the focus on the so-called resource-advantage theory of competition, illustrated by the so-called competitive position matrix, which showed that a company's market position and financial performance as a result of its comparative advantage is a function of the (1): relative resource-produced value; and (2) relative resource costs. This creates a 3-by-3 matrix where companies can be classified as being lower than, at parity with or superior to others across each of the two dimensions.

Hunt \& Morgan (1996, p. 107) also had to address Dickson's (1996) critique of the true dynamisms of their comparative advantage theory. They did this by emphasizing that both organizational learning and path dependency do not per se lead to superior performance, but that they are actually in many ways crafted through the ongoing process of dynamic competition and thus "much more contentious than Dickson's discussion suggests" (Hunt \& Morgan, 1996, p. 110). In their subsequent work, Hunt \& Morgan (1997, p. 81) also addressed Deligönül \& Çavuşgil’s (1997) critique of the alleged paradigmatic similarity of the Resource-advantage and the neoclassical market competition theories, and positioned it as both an alternative and complement to the latter by describing it as a "general" (Deligönül \& Çavuşgil, 1997, p. 82) and "interdisciplinary theory of competition [...which also accommodates...] institutional economics, socioeconomics [economic sociology], and evolutionary economics" (Hunt \& Morgan, 1997, p. 81). 


\subsection{Relationships as key competitive resources}

According to Ni (2006, p. 277), viewing relationships as resources satisfies all four resource criteria in the resource-based view perspective, namely (Barney, 1991): value; rareness; uniqueness (inimitability); and non-substitutability. This evolution stream of the relationships paradigm expanded the initial resource-based view theory of the firm by Penrose (1959/1995) - where human resources were considered as organizational resources (see Wright, Dunford \& Snell, 2001 for an overview) - into a wider focus on intangible resources and dynamic capabilities (Carpenter, Sanders \& Gregersen, 2001) as sources of strategic competitive advantage (Dyer \& Singh, 1998).

Intangible resources have become especially important in real-life market settings (as opposed to neoclassical market settings), with heterogeneous demand across and within industries, the existence of information asymmetries, and heterogeneous and not perfectly mobile resources (Hunt \& Morgan, 1995, p. 3). Such settings seem to be especially typical across national markets, and are thus especially applicable to TNCs (Porter, 1986). If today's economy is really a network economy (Barabasi, 2003), and most of the competition takes place across network-embedded companies (Dyer \& Singh, 1998) and their corresponding networks (Best, 1990), then relationships can be viewed as key resources (Morgan \& Hunt, 1994; Johnson \& Selnes, 2004), and their management is thus a key source of competitive advantage leading to a favorable market position and financial performance (Morgan \& Hunt, 1994). Relationships may be seen as a type of intangible, non-price "factors (sources) of firm competitiveness" (Makovec Brenčič, 2001, p. 313). They "are the most important sources of $C A$ [competitive advantage] of the firm [...] which directly and indirectly influence the position and performance of the firm in international markets" (Makovec Brenčič, 2001, p. 314).

Within a supply chain perspective, and particularly related to buyer-supplier relationships, Hunt \& Davis (2008) have called for the employement of the resource-advantage theory perspective in better understanding the competitive advanatge-building nature of buyer-supplier relationships and their management. Building on Hunt \& Davis' (2008) work, relationships should not simply be viewed as a crucial organizational resource - which act as a conduit to other resources (Hunt \& Davis, 2012) - but as drivers of sustainable competitive advantages through facilitating the flexibility of embeddedness and dissembeddedness, which Heidenreich (2012) describes as a key TNC competitive advantage building capability.

\subsection{The relational vs. the transaction view of buyer-supplier relationships}

Mudabi \& McDowell Mudabi (1995, p. 420) emphasize how the "analyses of buyer-supplier relations generally fall into one of two camps, transaction cost economics (TCE), or the more amorphous camp consisting of advocates of relationship marketing, the IMP model, Japanese management obligational relational contracting". Because of this view, we describe both of these perspectives before proceeding to our empirical illustrative example.

\subsubsection{Buyer-supplier relationships and transaction cost economics}

Transaction cost economics (TCE) essentially focused on the differences in cost between internalization of organizational processes and activities (e.g. production) vis-à-vis market transactions. The optimal buyer-supplier relationship was thus the one based on the lowest possible total cost, where internal operations costs were balanced with the costs of purchasing, planning, adapting and monitoring eternally transacted operations (Williamson, 1996). This fundamen- 
tally defined firm boundaries (Coase, 1937; Cox, 1996). According to Williamson, basically “[any] contracting problem can be examined to advantage in transaction cost economizing terms" (Williamson, 2010a, p. 230).

Related to buyer-supplier relationships, TCE approached such relationships as a set of discrete transactions between two parties from a completely rational stand point. While the decision to produce, source or do anything in between was based solely on the optimization of production costs vs. market transactions, the "efficiency of governance" was also taken into consideration (Lintukangas, 2007, p. 4). Grover \& Malhotra (1997) in relation to this argued that TCE perspectives to buyer-supplier relationship governance were particularly useful in connection to efficiency, flexibility and overall performance issues. Thus, the markets vs. hierarchies perspective has come to be seen not only as a key contribution to economic theory and business research (Dahlstrom \& Nygaard, 2010), but its "natural progression" also led it towards the governance perspective (Williamson, 2010b, p. 215).

Within TCE, Williamson's underlying hypothesis was also that suppliers (sellers) must fight for the interest of the buyers since buyers have the ultimate money-generating power (Ellegaard, Johansen \& Drejer, 2002, pp. 348-349). Williamson (1985) also outlined three dimensions of transaction relations, namely: (1) transaction-specific investments; (2) uncertainty; and (3) frequency. However, only the issue of TSI is usually applied (researched) to arrive at the optimal transaction governance (Claro, 2004, p. 27).

The main critique of TCE, however, concerns its atomized economic transactions, disregarding all other possible contingent relationships to this transaction (Cook \& Emerson, 1978). This point was also raised by Blomqvist, Kyläheiko \& Virolainen (2002) who pointed to the need for TCE to shift from a narrow cost perspective to a wider transaction benefits-based analysis. A second critique raised by Ring \& Van der Ven (1992) is that it presentsa set of discrete transaction types, not the evolution of governance mechanisms through time. A third point raised the question of actors being only opportunistic and led by self-interest, disregarding the gradual development of trust and commitment in long-term relationships (Powell, 1990; Barney \& Hesterly, 1999). A fourth and final critique was connected to Krapfel, Salmond \& Spekman's (1991) observation that the nature of transaction costs themselves actually determines the relationship types, which also determine the relationship governance (Lintukangas, 2007; also see Heide \& John, 1992). Thus, TCE did not adequately explain, e.g. "the influences of internal management and social relations" (Lintukangas, 2007, p. 5; cf. Ghoshal \& Moran, 1996).

Research proposition 1: Buyer-supplier relationship competitiveness will be determined by transaction-specific investments (TSIs), which represent the transactional aspect of buyer-supplier relationship management.

\subsubsection{Buyer-supplier relationships and relationship marketing}

With its focus on long-term and value-adding relationships, relationship marketing evolved as an alternative to TCE and its interest in transaction based exchanges (Sheth, Gardner \& Garett, 1988). According to Sheth \& Parvatiyar (1995), the emergence of the relationship marketing perspective in the marketing theory was marked by a paradigmatic shift to relationships, which came to the forefront of economics after the decline of neoliberal economic orthodoxy. It also corresponded to a pre-industrial era return to direct relationships in both $\mathrm{B} 2 \mathrm{~B}$ and $\mathrm{B} 2 \mathrm{~B}$ con- 
texts. In these two contexts, relationship marketing is interested not only in classic underlying parameters of economic exchanges, but also takes into account non-economic characteristics, especially trust and commitment, seen as important characteristics in social exchange-based relationships (Grönroos, 1997, p. 407). Because of this, the commitment-trust theory (Morgan \& Hunt, 1994) has become one of the fundamental theories within the relationship marketing paradigm, where trust and commitment are seen as mediators to the antecedents and determinants of buyersupplier relationship performance (Morgan \& Hunt, 1994). This has been empirically crossvalidated particularly in B2B marketing settings (e.g. Friman et al., 2002) and buyer-supplier alliances (Yang et al., 2008).

In the beginning, relationship marketing was seen as an attempt to "involve and integrate customers, suppliers and other infrastructural partners into a firm's developmental and marketing activities" (Sheth \& Parvatiyar, 1995, p. 399). In this regard, Morgan \& Hunt (1994, p. 22) provided one of the most universally recognized definitions of relationship marketing, namely its focus on all marketing activities conducted to create, develop, and manage successful relationships between marketing partners (e.g. suppliers and buyers). Another very good definition of relationship marketing is that of Veloutsu, Saren \& Tzokas (2002) who view relationship marketing as a philosophy for re-orientating buyers and suppliers through a business strategy. This brings them together in collaborative and cooperative ways, ensuring synergetic, trusting and mutually beneficial relationships.

Later, Hutt \& Speh (2004) emphasized the long-term and value-adding nature of such relational exchanges, while more recently the key emphasis has shifted to the mutuality of such long-term and value-adding relationships (LaPlaca, 2004; Streukens, van Hoesel \& de Ruyter, 2011) and the question of relative returns of such relationships (Streukens, van Hoesel \& de Ruyter, 2011; Rust, Zahorik \& Keiningham, 1995). Further, building on the so-called service-dominant logic of marketing (Vargo \& Lusch, 2008) or the broader service logic (Normann, 2001), Grönroos also emphasized the role of services as a "mediating factor" in the process of mutual buyer-supplier value creations, where true value is created not only through exchanges, but from active engagement and integration of partners in each other's processes (Grönroos, 2011, p. 240). This is more consistent with relationship marketing as a synonym for a network perspective on buyer-supplier relationships (Gummesson, 2000).

The reason relationship marketing theory is particularly applicable to buyer-supplier contexts is because it focuses on "close interactive [long-term] relationships with [particularly] suppliers, customers or other value chain partners of the firm" (Sheth \& Parvatiyar, 1995, p. 399). According to Sheth \& Parvatiyar (1995, p. 399), the "development of relationship marketing points to a significant shift in the axioms of marketing: competition and conflict to mutual cooperation, and choice independence to mutual interdependence".

Research proposition 2: Buyer-supplier relationship competitiveness will be determined by trust and joint problem solving, which represent the relational aspect of buyer-supplier relationship management. 


\section{ILLUSTRATIVE EXAMPLE}

\subsection{Data}

Our data was collected in the summer of 2011 through a web-based survey carried out in English, Slovenian, Russian and Serbian language. A sample of 130 international suppliers (approx. $30 \%$ response rate) was obtained and provides the basis for our analyses ( $n=130)$. We surveyed suppliers to a large TNC, headquartered in Slovenia, and with manufacturing operations in Slovenia, Russia, Serbia and the United Arab Emirates. The TNC describes itself as a leading manufacturer of complete solutions related to metal and steel constructions in Eastern Europe: It has a workforce of over 1,000 employees and world-wide revenues of close to 180 million EUR in 2011.

In terms of the characteristics of the surveyed suppliers, the average length of the supply relationship in our sample was 6.2 years (standard deviation of 4.8 years). A fifth of the surveyed suppliers were micro companies (up to nine employees), with an additional $55.5 \%$ being either small (10-50 employees) or medium-sized suppliers (51-250 employees). Almost $50 \%$ of the surveyed suppliers were from Slovenia, followed by some $20 \%$ from EU and Switzerland, while the remaining suppliers were from Russia (18.9\%) and Serbia (13.2\%). Generally speaking, the surveyed suppliers were quite independent from the TNC in terms of revenue generation, since $50 \%$ of them generated only up to $1 \%$ of their annual revenues from supplies to the TNC, and an additional $29 \%$ between $1.1 \%$ and $5 \%$ of their annual revenues.

\subsection{Methodology}

In our research we employ Structural equation modeling (SEM). This is done within a simple SEM of main effects where we test the impact of selected relational and transaction dimensions on overall buyer-supplier relationship competitiveness, as the key dependent construct. We employed SEM in our research, not only as one of the most important and widely employed modeling approaches in the marketing literature (Steenkamp \& Baumgartner, 2000), but because it enables the testing of relationships between multiple independent and dependent latent constructs (Ullman, 2006). Such constructs, as e.g. trust, cannot be directly observed or measured. Instead they are either reflected through particular manifest variables (reflective models) or impacted by specific manifest variables (formative models) (Diamantopoulos \& Siguaw, 2006). These kinds of constructs are quite common in social sciences, organizational research and particularly in the field of marketing (Steenkamp \& Baumgartner, 2000). SEM is a two-step modeling process of first testing how specific manifest (observable) variables represent a given latent construct - this corresponds to the estimation of the measurement model (emphasis on reliability and validity as discussed in Table 2) - followed by testing the relationships between the specific latent constructs through a series of structural equations - this corresponds to estimation of the structural model which is shown in Figure 1, and focuses on the estimation of path coefficients between the tested latent constructs (Schumacker \& Lomax, 1996).

Within the SEM approach we employed a variance-based SEM approach, based on Partial Least Squares (PLS). Readers unfamiliar with PLS SEM are advised to refer to Esposito Vinzi et al. (2010) for a comprehensive description and overview of the method. This modeling approach 
has started to gain increasing popularity within marketing (Hensler, Ringle \& Sinkovics, 2009). We employed PLS SEM because we wanted to establish the predictive power of our model, since this model was tested as a simple SEM with main effects. Furthermore, we employed PLS SEM also because of the large number of manifest variables (altogether 29 items in the questionnaire) across nine different reflective constructs vis-a-vis a sample size of only 130 respondents. Another reasons for employing PLS SEM was also the non-normal distribution of all of the nine constructs (as composite variables) - the results of this testing are available upon request - which made the use of a covariance-based SEM less appropriate. This is because traditional covariancebased SEM, using Ordinary Least Squares (OLS) requires not only a much larger sample size, but is only appropriate for normally distributed data (Esposito Vinzi et al., 2010). In addition, since all of the surveyed suppliers were connected to a single focal TNC and almost half of them coming from the same country (Slovenia), this represents a higher likelihood of observation interdependency (multicolinearity) for which again variance-based SEM is more suitable, compared to covariance-based SEM (Hensler, Ringle \& Sinkovics, 2009).

Table 1 displays the operationalization and theoretical background of the analyzed constructs, analyzed in our research as latent reflective constructs. Furthermore, the Appendix at the end of the paper provides a list of all the questions from the original questionnaire.

Tab. 1 - Constructs' operationalization and theoretical background. Source: Authors' own review of the referenced literature

\begin{tabular}{|l|l|l|}
\hline CONSTRUCT & OPERATIONALIZATION & $\begin{array}{l}\text { THEORETICAL } \\
\text { REFERENCE }\end{array}$ \\
\hline Relationship-based information & $\begin{array}{l}\text { 5items of shared information be- } \\
\text { tween TNC and supplier regard- } \\
\text { ing: (1) prices, (2) quantities, (3) } \\
\text { logistic operations, (4) production } \\
\text { process, (5) future actions }\end{array}$ & $\begin{array}{l}\text { Claro, 2004; Anderson, } \\
\text { Håkansson \& Johanson, } \\
1994 ; \text { Blakenburg, Eriksson \& } \\
\text { Johanson, 1999 }\end{array}$ \\
\hline $\begin{array}{l}\text { Physical assets-based transaction- } \\
\text { specific investments (TSI) }\end{array}$ & $\begin{array}{l}\text { 3items: (1) significant supply } \\
\text { relationship investments, (2) } \\
\text { specific adjustments in organiza- } \\
\text { tional processes, (3) significant } \\
\text { commitment to specific internal } \\
\text { process and organization }\end{array}$ & $\begin{array}{l}\text { Heide \& John, 1992; Bensaou } \\
\text { \& Venkatraman, 1995 }\end{array}$ \\
\hline People based transaction-specific \\
investments (TSI) & $\begin{array}{l}\text { 3items: (1) learning about } \\
\text { partner's business practices, (2) } \\
\text { additional activities, training and } \\
\text { education, (3) losing knowledge } \\
\text { about partner's operation if } \\
\text { relationship is terminated }\end{array}$ & $\begin{array}{l}\text { Heide \& John, 1992; Bensaou } \\
\text { \& Venkatraman, 1995 }\end{array}$ \\
\hline
\end{tabular}




\begin{tabular}{|c|c|c|}
\hline Interorganizational trust & $\begin{array}{l}3 \text { items: (1) TNC unit open- } \\
\text { ness/honesty in negotiations, (2) } \\
\text { TNC unit trustworthiness, (3) } \\
\text { TNC unit looking out for partner } \\
\text { interests }\end{array}$ & $\begin{array}{l}\text { Zaheer, McEvily \& Perrone, } \\
1998\end{array}$ \\
\hline Interpersonal trust & $\begin{array}{l}3 \text { items: (1) contact person's open- } \\
\text { ness/honesty in negotiations, (2) } \\
\text { contact person's trustworthiness, } \\
\text { (3) contact person looking out for } \\
\text { partner interests }\end{array}$ & $\begin{array}{l}\text { Zaheer, McEvily \& Perrone, } \\
1998\end{array}$ \\
\hline Joint planning & $\begin{array}{l}3 \text { items of joint planning con- } \\
\text { nected to: (1) volume demands, } \\
\text { (2) long-term plans for new } \\
\text { products, (3) sales forecasts }\end{array}$ & $\begin{array}{l}\text { Heide \& John, } 1990 \text { \& 1992; } \\
\text { Heide \& Miner, 1992; Lush \& } \\
\text { Brown, } 1996\end{array}$ \\
\hline Joint problem solving & $\begin{array}{l}3 \text { items of joint problem solving } \\
\text { connected to: (1) dealing with } \\
\text { problems jointly, (2) shared } \\
\text { responsibility, (3) commitment to } \\
\text { improvements }\end{array}$ & $\begin{array}{l}\text { Heide \& John, } 1990 \text { \& 1992; } \\
\text { Heide \& Miner, 1992; Lush \& } \\
\text { Brown, } 1996\end{array}$ \\
\hline Relationship flexibility & $\begin{array}{l}\text { Efficient response in a supply } \\
\text { relationship to: (1) day-to-day (op- } \\
\text { erational) changes, (2) occasional } \\
\text { (e.g. quarterly tactical) changes, } \\
\text { (3) substantive, long-term, and } \\
\text { rare (strategic) changes (efficient } \\
=\text { with minimal impact /degrada- } \\
\text { tion on performance) }\end{array}$ & Golden \& Powel, 2000 \\
\hline Supply relationship competitiveness & $\begin{array}{l}3 \text { items connected to: (1) SCM } \\
\text { as an important source of TNC } \\
\text { competitive advantage, (2) } \\
\text { increased competitiveness of } \\
\text { supplier due to relationship with } \\
\text { TNC, (3) efficient SCM leading } \\
\text { to dyadic buyer-supplier higher } \\
\text { competitiveness (vis-à-vis market } \\
\text { competition) }\end{array}$ & $\begin{array}{l}\text { Veludo, Macbeth \& Purchase, } \\
\text { 2006; Dyer \& Singh, 1998; } \\
\text { Harland, } 1996\end{array}$ \\
\hline
\end{tabular}

\subsection{Results}

Table 2 first presents the key statistics related to the overall quality of our PLS SEM of main effects. The information in Table 2 is presented according to established practice of reporting reliability and validity statistics of SEM within marketing, as well as according to Chin's (2010) guidelines for reporting PLS SEM quality statistics. 
The second column of Table 2 first displays the mean scores (7-point scale) for each of the modeled latent constructs in our analysis. Each mean score was calculated as a simple average from all the items reflecting a specific latent construct (see Appendix for original questionnaire items belonging to a specific construct). From these descriptive statistics we can see, for example, that among the modeled constructs interpersonal- and interorganizational trust display the highest mean scores (5.42 and 5.32 respectively), which can be explained by long-lasting and established nature of our surveyed supplier relationships (average supply relationship length of 6.2 years). On the other hand, joint planning displays the lowest relative mean score (3.91), which can be explained by a high power asymmetry between the large TNC and their smaller suppliers, which act mostly as pipelines of supplies.

The third column presents information about internal reliability statistics for each of the modeled constructs measured with Cronbach's $\alpha$. Since all $\alpha$ values were above the 0.7 threshold, we can conclude that individual items corresponding to a specific latent construct, indeed measure the same construct. The remaining columns within Table 2 correspond to a inter-construct correlation matrix, displaying pair-wise correlation coefficients between each of the nine modeled latent constructs in our PLS SEM. With regards to these pair-wise correlation coefficients, most of them display relatively low or moderate pair-wise correlations, thus indicating acceptable levels of multicolinearity. On the other hand, only three pair-wise correlation coefficients are higher than 0.7 - namely between physical asset-based and people-based transaction-specific investments $(\beta=0.72)$ and between joint problem solving and interorganizational trust $(\beta=0.72)$, as well as between interpersonal and interorganizational trust $(\beta=0.83)$. Despite a high pair-wise correlation between the latter two constructs, Zaheer, McEvily \& Perrone (1998) clearly emphasize that these two constructs are not merely different dimensions of organizational trust, but different trust constructs belonging to different levels; and should thus be analyzed separately.

With regards to the inter-construct correlation matrix presented in Table 2, it is also important to point to another feature of the matrix. The diagonal values of the matrix - which should be zero in a correlation matrix - have been replaced with the values of the square roots of the Average variance extracted (AVE). This is again in-line with recommendations on how to appropriately report PLS SEM results, as outlined by China (2010). AVE measures the so called convergent validity of each latent construct. It represents the average share of variance explained by the latent construct among all the items (manifest variables) measuring that construct. Appropriate convergent validity of the constructs is achieved, when AVE $>0.5$ for each construct (Fornell \& Larcker, 1981). Additionally, if the square root values of AVE on the inter-construct correlation matrix diagonal are larger than any single pair-wise correlation coefficient between any two constructs (values below the matrix diagonal), this further satisfies the requirements for appropriate discriminant validity of our PLS SEM model, as pointed out by Chin (2010). Comparing the square root AVE values on the diagonal in Table 2 to each individual pair-wise correlation coefficient between any two constructs, we can conclude that our PLS SEM model of main effects shown in Figure 1 also satisfies both types of validity criteria. 
Tab. 2 - Constructs' correlation matrix and descriptive statistics. Source: Suppliers' survey, 2011 $(\mathrm{n}=130)$.

\begin{tabular}{|c|c|c|c|c|c|c|c|c|c|c|c|}
\hline Construct & $\sum_{\Sigma}^{\mathbb{J}}$ & 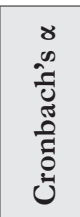 & 1 & 2 & 3 & 4 & 5 & 6 & 7 & 8 & 9 \\
\hline (1) Competitiveness & 4.40 & 0.80 & 0.85 & & & & & & & & \\
\hline $\begin{array}{l}\text { (2) Relationship- } \\
\text { based information }\end{array}$ & 5.08 & 0.83 & 0.41 & 0.77 & & & & & & & \\
\hline $\begin{array}{l}\text { (3) Physical assets- } \\
\text { based TSI }\end{array}$ & 4.81 & 0.74 & 0.56 & 0.13 & 0.81 & & & & & & \\
\hline $\begin{array}{l}\text { (4) People based } \\
\text { TSI }\end{array}$ & 4.17 & 0.75 & 0.57 & 0.23 & 0.72 & 0.80 & & & & & \\
\hline (5) Interorg. trust & 5.32 & 0.90 & 0.55 & 0.55 & 0.13 & 0.12 & 0.91 & & & & \\
\hline $\begin{array}{l}\text { (6) Interperson. } \\
\text { trust }\end{array}$ & 5.42 & 0.93 & 0.67 & 0.45 & 0.23 & 0.21 & 0.83 & 0.94 & & & \\
\hline (7) Joint planning & 3.91 & 0.86 & 0.64 & 0.37 & 0.46 & 0.54 & 0.41 & 0.54 & 0.88 & & \\
\hline $\begin{array}{l}\text { (8) Joint problem } \\
\text { solving }\end{array}$ & 5.28 & 0.79 & 0.59 & 0.46 & 0.11 & 0.12 & 0.72 & 0.66 & 0.49 & 0.84 & \\
\hline $\begin{array}{l}\text { (9) Relationship } \\
\text { flexibility }\end{array}$ & 4.95 & 0.89 & 0.47 & 0.37 & 0.40 & 0.40 & 0.37 & 0.49 & 0.38 & 0.25 & 0.90 \\
\hline
\end{tabular}

Notes: Cronbach's $\alpha$ values report internal reliability $(\alpha>0.7)$; AVE values report convergent validity (AVE $>0.5)$; square roots of AVE on correlation matrix diagonal measure discriminant validity:

$\sqrt{\mathrm{AVE}}>$ any pairwise construct correlation coefficient

Having presented descriptive and SEM model quality statistics in Table 2, the results of our variance-based reflective PLS SEM model are shown in Figure 1. First, with regards to the measurement part of the model, we can see that all of the 29 manifest variables display very high factor loadings, and are thus a good reflection of their corresponding latent constructs. In particular, all three manifest variables [q5d, q5f] belonging to the construct of interpersonal trust, display loading above 0.9 .

In terms of the structural part of the model, we can see that only four out of the eight exogenous reflective constructs have statistically significant path coefficients. Among them the reflective construct of interpersonal trust has the highest path coefficient $(\gamma=0.391 ; \mathrm{p} \leq 0.01)$, followed by joint problem solving $(\gamma=0.278 ; \mathrm{p} \leq 0.05)$, people-based TSI $(\gamma=0.254 ; \mathrm{p} \leq 0.05)$ and physical assets-based TSI $(\gamma=0.230 ; \mathrm{p} \leq 0.05)$. This tells us that within our simple SEM with main effects interpersonal trust has the strongest, single and positive impact on buyer-supplier relationship competitiveness. We can also observe that among these four latent constructs three constructs are relationship-based constructs, while only the fourth construct (physical assets-based TSI) is a "pure" transactional construct. 


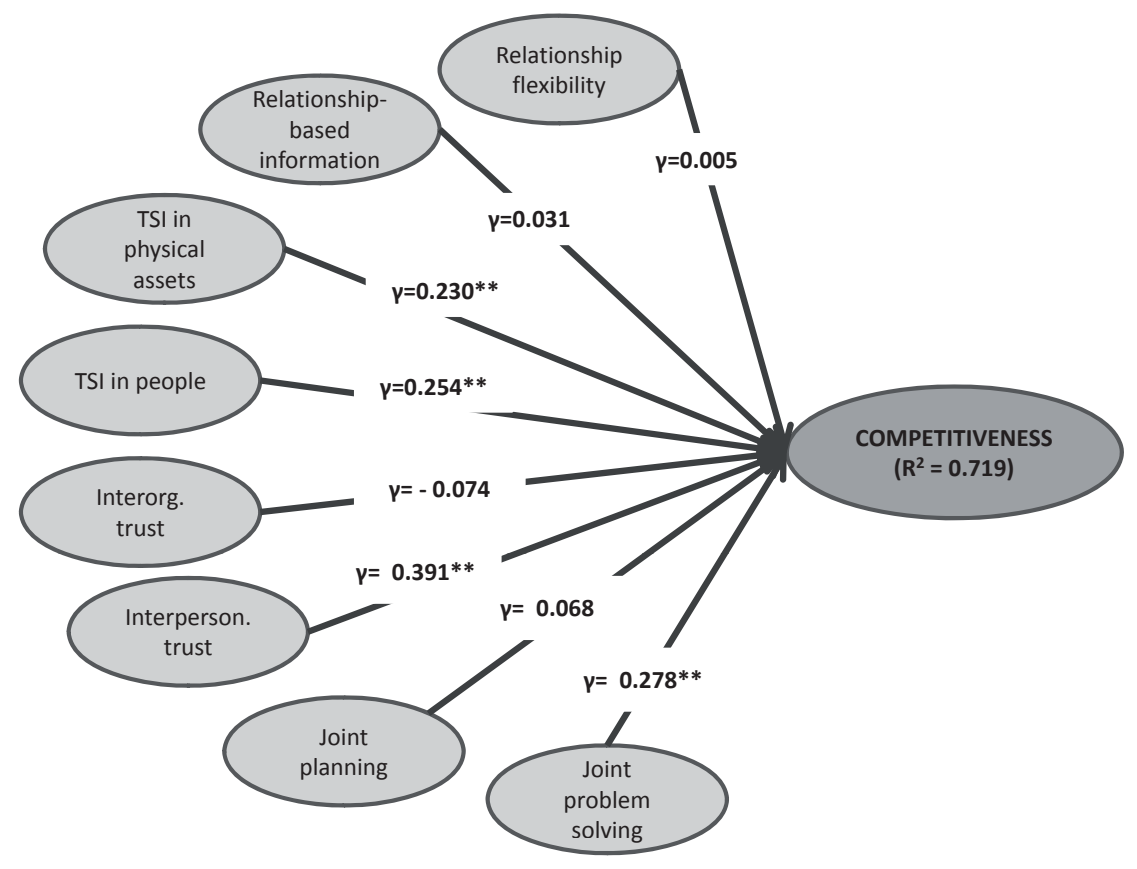

Fig. 1 - Transactional and relational determinants of buyer-supplier relationship competitiveness - simple SEM of main effects, tested as a PLS SEM. Source: Suppliers' survey, $2011(n=130)$. Note: ** $p \leq 0.05$.

Besides the specific path coefficients within the structural part of our SEM, it is also important to emphasize that our simple SEM of main effects produced a very good adjusted $\mathrm{R}^{2}$ value of 0.72 for the endogenous reflective construct of buyer-supplier relationship competitiveness. This indicates that such competitiveness is to a large degree determined by interpersonal trust and joint problem solving, as well as people based TSI and physical assets-based TSI. Furthermore, a large degree of such relationship competitiveness can be explained through main effects of the four aforementioned constructs. Next, we discuss the theoretical and managerial implications of our results.

\section{DISCUSSION AND CONCLUSION}

\subsection{Theoretical implications from our illustrative example}

The results of our analysis have confirmed the multi-dimensional nature of organizational competitiveness, which calls for the employment of multiple criteria (Šebo \& Šebová, 2010). Our illustrative empirical evidence has clearly shown that relationships, and in particular buyer-supplier relationships, are key intangible organizational resources, thus confirming the earlier work by Morgan \& Hunt (1994), Hunt (2000), and Ni (2006). By estimating the impact of selected relational and transaction dimensions directly on buyer-supplier relationship competitiveness our results provide a clear and direct support of Hunt \& Morgan's (1995) resource-advantage theory of competition. 
The importance of trust, as a central relational dimension of buyer-supplier relationships on the one hand supports Morgan \& Hunt's (1994) trust-commitment theory. Yet, this is not all. By establishing only interpersonal trust (but not interorganizational trust) as the central relational driver of buyer-supplier relationship competitiveness this shows that trust as a social mechanism takes on a very personal dimension in TNCs, which function as differentiated interorganizational networks (Ghoshal \& Bartlett, 1990). This mechanism becomes very personal, particularly in contexts with high buyer-supplier size and power asymmetry. This was the case in our supplier sample. In addition to trust, the importance of joint problem solving further supports Van Auken's (2001, p. 29) resource-advantage perspective by outlining a social mechanism through which collaborative relationships acts as a "catalyst for superior market positioning and attendant financial success". Together our results point to two types of relational mechanisms impacting buyer-supplier relationship competitiveness. The first one is related to Morgan \& Hunt's (1994) trust-commitment theory, while the second one is related to the so called collaborative paradigm in such relationships (Chen \& Paulraj, 2004).

While Hunt \& Morgan (1995) have actually positioned their resource-advantage theory as an alternative theory of competition, our empirical evidence shows that this needn't necessarily be the right view, since relational dimensions can be seen as a complement to transactional dimensions of buyer-supplier competitiveness. This may be particularly true in well-established buyer-supplier relationships. We believe that Morgan \& Hunt's (1994) trust-commitment theory provides an excellent substantive interface between the relationship marketing perspective of buyer-supplier relationships and its transaction cost economics counterpart. This is visible not only through two types of determinants of buyer-supplier relationship competitiveness, namely the relational and transactional ones, but also through the importance of people-based TSIs, as part of transactional determinants of such competitiveness.

\subsection{Some managerial recommendations from our illustrative example}

In terms of our recommendations to managers we can say that TNC managers should pay equal (if not even larger) attention to relational dimensions in their buyer-supplier relationships vis-àvis existing transactional dimensions, especially in well-established buyer-supplier relationships. In the context of these relational dimensions trust may be seen as the key relational driver of buyer-supplier relationship competitiveness. Further, the fact that interpersonal trust was the strongest and most significant determinant of such competitiveness, not interorganizational trust, shows that such relationships need to be not only understood but also managed as people-to-people relationships. This is regardless of the size of the companies behind these relationships and the complexity of the TNC as a large inter- and intraorganizational differentiated network (Ghoshal \& Bartlett, 1990).

Second, each relationship is prone to conflicts and problems. In this regard, joint problem solving should be seen as the second key managerial tool which drives not only buyer-supplier relationship competitiveness, but also facilitates trust as well. Having said this, TNC managers should pay special attention to developing specific problem solving mechanisms, which facilitate not only intraorganizational but also interorganizational collaboration between the parties involved. These mechanisms should be again people-to-people based and aimed at strengthening interpersonal trust. 
Lastly, while TNC managers are aware that transaction-specific investments are an important part of each buyer-supplier relationship, the fact that people-based TSIs have a relatively stronger impact on buyer-supplier relationship competitiveness compared to physical assets-based TSIs again shows the important of relationship-specific people-based TSIs. Having said this, TNC managers should make sure that physical assets-based TSIs are accompanied by people-based TSIs, by paying special attention to not only training, but also internal communication and organizational culture.

\subsection{Concluding thoughts}

The purpose of this paper has been to illustrate how the so called resource-advantage perspective can be used to analyze the importance of specific relational and transactional dimensions of buyer-supplier relationships in driving relationship competitiveness within a transnational company (TNC) context. By testing a simple variance-based SEM of main effects we were able to show the importance of understanding the relational dimensions of TNC buyer-supplier relationships as key intangible resource for competitive advantage within Hunt \& Morgan's (1995) resource-advantage theory of competition. Additionally, we were also able to point to specific social mechanisms behind the impact of particularly relational dimensions on buyer-supplier relationship competitiveness; as well as that the relational and transactional perspectives to buyer-supplier relationship management as a source of competitive advantage in TNCs should be seen as complementary, not opposing perspectives. This was discussed already by Mudabi \& McDowell Mudabi (1995), but without a more detailed examination of the importance of specific relational and transactional relationship dimensions.

We fully acknowledge the limitations of our illustrative single TNC case study approach, as well as the simple nature of our model main effects, which does not include any moderator or mediator effects, and should be further expanded in the future. Additionally, our research incorporates only the suppliers' perspective and not the TNC's perspective. Since the TNC is a large company and most of the suppliers were micro, small or medium-sized companies the power asymmetry in their corresponding buyer-supplier relationships should be taken into account. While the use of single respondents can open the door to a potential for an additional common method bias, in most cases these respondents may actually be the only involved parties in the underlying supply relationships, given the small size of the surveyed suppliers.

Despite being aware of the limitations of our research we still feel that the results provide a substantive basis for some theoretical and managerial implications. We also hope that they will motivate additional cross-validations of our work, as well as further research in understanding the intangible resource-advantage-based perspective of TNC buyer-supplier relationships and their competitiveness. Such competitiveness has been shown to be very much relationship based, as well as surprisingly personal. 


\section{References}

1. Alderson, W. (1957). Marketing Behavior and Executive Action. Homewood, IL: Richard D. Irwin.

2. Alderson, W. (1965). Dynamic Marketing Behavior. Homewood, IL: Richard D. Irwin.

3. Anderson, J. C., Håkansson, H. \& Johanson, J. (1994). Dyadic business relationship within a business network context. Journal of Marketing, 58(4), 22-38. http://dx.doi. org/10.2307/1251912

4. Barabasi, A.-L. (2003). Linked: How Everything is Connected to Everything Else and What it Means. New York, NY: Plume Book.

5. Barney, J. B. (1991). Firm Resources and Sustained Competitive Advantage. Journal of Management, 17 (1), 99-120. http://dx.doi.org/10.1177/014920639101700108

6. Barney, J. B. \& Hesterly, W. (1999). Organizational economic: understanding the relationship between organizations and economic analysis. In S. R. Clegg, \& C. Hardy, (Eds.), Studying Organization (109-141). London, UK: Sage Publication.

7. Bartlett, C. A. \& Ghoshal, S. (1989). Managing across borders: the transnational solution. Cambridge, MA: Harvard Business School Press.

8. Bensaou, M. \& Venkatraman, N. (1995). Configurations of inter-organizational relationships: a comparison between U.S. and Japanese automakers. Management Science, 41(9), 1471-1492. http://dx.doi.org/10.1287/mnsc.41.9.1471

9. Bharadwaj, S. G., Varadarajan, P. R. \& Fahy, J. (1993). Sustainable competitive advantage in service industries: a conceptual model and research propositions. Journal of Marketing, 57(4), 83-99. http://dx.doi.org/10.2307/1252221

10. Blakenburg Holm, D., Eriksson, K. \& Johanson, J. (1999). Creating value through mutual commitment to business network relationships. Strategic Management Journal, 20(5), 467-486. http://dx.doi.org/10.1002/(SICI)1097-0266(199905)20:5<467::AID-SMJ38>3.0.CO;2-J

11. Blomqvist, K., Kyläheiko, K. \& Virolainen, V.-M. (2002). Filling a gap in traditional transaction cost economics: Towards transaction benefits-based analysis. International Journal of Production Economics, 79(1), 1-14. http://dx.doi.org/10.1016/S0925-5273(00)00095-5

12. Carpenter, M. A., Sanders, W. C. \& Gregersen, H. B. (2001). Building human capital with organizational context: The impact of international experience on multinational firm performance and CEO pay. Academy of Management Journal, 44(3), 493-511. http://dx.doi. org $/ 10.2307 / 3069366$

13. Chen, I.J. \& Paulraj, A. (2004). Towards a theory of supply chain management: the constructs and measurement. Journal of Operations Management, 22(2), 119-150. http://dx.doi. org/10.1016/j.jom.2003.12.007

14. Chin, W. W. (2010). How to Write Up and Report PLS Analyses. In Esposito Vinzi, V., Chin, W. W., Hensler, J. \& Wang, H. (Eds.), Handbook of Partial Least Squares: Concepts, Methods and Applications (655-690), Berlin \& Heidelberg, Germany: Springer.

15. Clark, M. J. (1961). Competition as a dynamic process. Washington, D. C: Brookings Institution.

16. Claro, D. P. (2004). Managing business networks in buyer-supplier relationships: how information obtained from the business network affects trust, transaction specific investments, collaboration and performance in the Dutch Potted Plant and Flower Industry. Doctoral dissertation. Wageningen, The Netherlands: Wageningen University and Research Centre. 
17. Coase, R. H. (1937). The Nature of the Firm. Economica, 4(16), 386-405. http://dx.doi. org/10.1111/j.1468-0335.1937.tb00002.x

18. Cook, K. S. \& Emerson, R. M. (1978). Power, Equity and Commitment in Exchange Networks. American Sociological Review, 43(10), 721-739. http://dx.doi.org/10.2307/2094546

19. Cox, A. (1996). Relational competence and strategic procurement management. Towards an entrepreneurial and contractual theory of the firm. European Journal of Purchasing \& Supply Management, 2(1), 57-70. http://dx.doi.org/10.1016/0969-7012(95)00019-4

20. Dahlstrom, R. \& Nygaard, A. (2010). Epilogue: Popperian perspectives on transaction cost economics and future directions of empirical research. Journal of Retailing, 86(3), 284-290. http://dx.doi.org/10.1016/j.jretai.2010.07.010

21. Day, G. \& Wensley, R. (1988). Assessing Advantage: A Framework for Diagnosing Competitive Superiority. Journal of Marketing, 52(2), 1-20. http://dx.doi.org/10.2307/1251261

22. Day, G. \& Nedungadi, P. (1994). Managerial Representations of Competitive Advantage. Journal of Marketing, 58(2), 31-44. http://dx.doi.org/10.2307/1252267

23. Deligönül, S. \& Çavuşgil, S. T. (1997). Does the Comparative Advantage Theory Really Replace the Neoclassical Theory of Perfect Competition? Journal of Marketing, 61(1), 65-73. http://dx.doi.org/10.2307/1252087

24. Diamantopoulos, A. \& Siguaw, J. A. (2006). Formative Versus Reflective Indicators in Organizational Measure Development : A Comparison and Empirical Illustration. British Journal of Management, 17(4), 263-282. http://dx.doi.org/10.1111/j.1467-8551.2006.00500.x

25. Dickson, P. R. (1992). Toward a theory of competitive rationality. Journal of Marketing, 56(1), 69-83. http://dx.doi.org/10.2307/1252133

26. Dickson, P. R. (1996). The static and dynamic mechanisms of competition: a comment on Hunt and Morgan's comparative advantage theory. Journal of Marketing, 60(4), 102-106. http://dx.doi.org/10.2307/1251904

27. Dyer, J. H. \& Singh, H. (1998). The relational view: cooperative strategy and sources of interorganizational competitive advantage. Academy of Management Review, 23(4), 660-679. http://dx.doi.org/10.2307/259056

28. Ellegaard, C., Johansen, J. \& Drejer, A. (2002). Managing industrial buyer-supplier relationships: the case for attractiveness. Integrated Manufacturing, 14(4), 346-356. http:// dx.doi.org/10.1108/09576060310469725

29. Esposito Vinzi, V., Chin, W. W., Hensler, J. \& Wang, H. (Eds.) (2010). Handbook of Partial Least Squares: Concepts, Methods and Applications. Berlin \& Heidelberg, Germany: Springer. http://dx.doi.org/10.1007/978-3-540-32827-8

30. Fornell, C. \& Larcker, D. F. (1981). Evaluating Structural Equation Models with Unobservable Variables and Measurement Error. Journal of Marketing Research, 18(1), 39-50. http://dx.doi.org/10.2307/3151312

31. Friman, M., Garling, T., Millet, B., Mattson, J. \& Johnston, R. (2002). An analysis of international business-to-business relationships based on the Commitment-Trust theory. Industrial Marketing Management, 31(5), 403-410. http://dx.doi.org/10.1016/S00198501(01)00154-7

32. Gaddé, L.-E. \& Håkansson, H. (2001). Supply Network Strategies. Chichester, UK: John Wiley. 
33. Ghoshal, S. \& Bartlett, C. A. (1990). The Multinational Corporation as an Interorganizational Network. The Academy of Management Review, 15(4), 603-625. http:// dx.doi.org/10.5465/AMR.1990.4310825

34. Ghoshal, S. \& Moran, P. (1996). Bad for practice: a critique of the transaction cost theory. Academy of Management Review, 21(1), 13-47. http://dx.doi.org/10.5465/AMR.1996.9602161563

35. Golden, W. \& Powell, P. (2000). Towards a definition of flexibility: in search of the Holy Grail? Omega, 28(4), 373-384. http://dx.doi.org/10.1016/S0305-0483(99)00057-2

36. Griffith, D. A. \& Myers, M.B. (2005). The Performance Implications of Strategic Fit of Relational Norm Governance Strategies in Global Supply Chain Relationships. Journal of International Business Studies, 36(3), 254-269. http://dx.doi.org/10.1057/palgrave.jibs.8400131

37. Grover, V. \& Malhotra, V. (1997). Business process reengineering: a tutorial on the concept of evolution, method, technology and application. Journal of Operations Management, 15(3), 192-213. http://dx.doi.org/10.1016/S0272-6963(96)00104-0

38. Grönroos, C. (1997). Value-Driven Relational Marketing: From Products to Resources and Competencies. Journal of Marketing Management, 13(5), 407-419. http://dx.doi.org/10.1080/ 0267257X.1997.9964482

39. Grönroos, C. (2011). A service perspective on business relationships: The value creation, interaction and marketing interface. Industrial Marketing Management, 40(2), 240-247. http:// dx.doi.org/10.1016/j.indmarman.2010.06.036

40. Gummesson, E. (2000). Qualitative Methods in Management Research. Thousand Oaks, CA: Sage.

41. Harland, C. M. (1996). Supply Chain Management: Relationships, Chains and Networks. British Journal of Management, 7(Special issue), 63-80. http://dx.doi.org/10.1111/j.14678551.1996.tb00148.x

42. Heide, J. B. \& John, G. (1990). Alliances in Industrial Purchasing: The Determinants of Joint Action in Buyer-Supplier Relationships. Journal of Marketing Research, 27(1), 24-36. http://dx.doi.org/10.2307/3172548

43. Heide, J. B. \& John, G. (1992). Do norms matter in relationship marketing? Journal of Marketing, 56(2), 32-44. http://dx.doi.org/10.2307/1252040

44. Heide, J. B. \& Miner, A.S. (1992). The shadow of the future: effects of anticipated interaction and frequency of contact on buyer-seller cooperation. Academy of Management Journal, 35(2), 265-291. http://dx.doi.org/10.2307/256374

45. Heidenreich, M. (2012). The social embeddedness of multinational companies: a literature review. Socio Economic Review, 10(3), 549-579. http://dx.doi.org/10.1093/ser/mws010

46. Hensler, J., Ringle, C. M. \& Sinkovics, R. R. (2009). The use of partial least squares path modeling in international marketing. Advances in International Marketing, 20, 277-319.

47. Hunt, S. D. (1991). Modern Marketing Theory: Critical Issues in the Philosophy of Marketing Science. Cincinnati, OH: Southwestern Publishing.

48. Hunt, S. D. \& Morgan, R. M. (1995). The Comparative Advantage Theory of Competition. Journal of Marketing, 59(2), 1-15. http://dx.doi.org/10.2307/1252069

49. Hunt, S. D. \& Morgan, R. M. (1996). The Resource-Advantage Theory of Competition: Dynamics, Path Dependencies and Evolutionary Dimensions. Journal of Marketing, 60(3), 107-114. http://dx.doi.org/10.2307/1251905 
50. Hunt, S. D. \& Morgan, R.M. (1997). Resource-Advantage Theory: A Snake Swallowing Its Tail or a General Theory of Competition? Journal of Marketing, 61(4), 74-82. http://dx.doi. org/10.2307/1252088

51. Hunt, S. D. (2000). A General Theory of Competition: Resources, Competences, Productivity, Economic Growth. Thousand Oaks, CA: Sage Publications.

52. Hunt, S. D. \& Davis, D. F. (2008). Grounding Supply Chain Management in ResourceAdvantage Theory. Journal of Supply Chain Management, 44(1), 10-21. http://dx.doi. org/10.1111/j.1745-493X.2008.00042.x

53. Hunt, S. D. \& Davis, D. F. (2012). Grounding Supply Chain Management in ResourceAdvantage Theory: In Defense of a Resource-Based View of the Firm. Journal of Supply Chain Management, 48(2), 14-20. http://dx.doi.org/10.1111/j.1745-493X.2012.03266.x

54. Hutt, M. D. \& Speh, W. T. (2004). Business Marketing Management: A Strategic View of Industrial and Organizational Markets. Orlando, FL: Harcourt.

55. Hymer, S. H. (1979). The multinational corporation: a radical approach. Cambridge, MA: Cambridge University Press.

56. Johnson, M. D. \& Selnes, F. (2004). Customer Portfolio Management: Toward a Dynamic Theory of Exchange Relationships. Journal of Marketing, 68(2), 1-17. http://dx.doi. org/10.1509/jmkg.68.2.1.27786

57. Kaufman, A., Wood, C. H. \& Theyel, G. (2000). Collaboration and technology linkages: a strategic supplier typology. Strategic Management Journal, 21(6), 649-663. http://dx.doi. org/10.1002/(SICI)1097-0266(200006)21:6<649::AID-SMJ108>3.0.CO;2-U

58. Krapfel, R. E., Salmond, D. \& Spekman, R. (1991). A Strategic Approach to Managing Buyer-Seller Relationships. European Journal of Marketing, 25(9), 22-37. http://dx.doi. org/10.1108/EUM0000000000622

59. LaPlaca, P. J. (2004). Special Issue on Customer Relationship Management. Industrial Marketing Management, 33(6), 463-464. http://dx.doi.org/10.1016/j.indmarman.2004.04.001

60. Lintukangas, K. (2007). Theoretical frames for studying supplier relationship management in global purchasing. Paper presented at the 13th IFPSM Summer School on Advanced Purchasing Research, Salzburg, Austria, $5^{\text {th }}-10^{\text {th }}$ July 2007, IFPSM.

61. Lush, R. F. \& Brown, J. R. (1996). Interdependency, contracting, and relational behavior in marketing channels, Journal of Marketing, 60(4), 19-38. http://dx.doi.org/10.2307/1251899

62. Makovec Brenčič, M. (2000). Soodvisnost cenounih in necenovnih dejavnikov konkurenčnih prednosti podjetij v mednarodnem poslovanju. Doctoral dissertation. Ljubljana, Slovenia: University of Ljubljana, Faculty of Economics.

63. Makovec Brenčič, M. (2001). Analyzing competitive advantages on the basis of the resource-based view: the concept of price and non-price factors. Journal for East European Management Studies, 6(3), 313-330.

64. Morgan, R. M. \& Hunt, S. D. (1994). The Commitment-Trust Theory of Relationship Marketing. Journal of Marketing, 58(3), 20-38. http://dx.doi.org/10.2307/1252308

65. Morgan, G., Kristensen, H. P. \& Whitley, R. (2003). The Multinational Firm: organizing across institutional and national divides. Oxford, UK: Oxford University Press.

66. Mráček, P. \& Mucha, M. (2011). Application of knowledge in advergaming as a possible source of competitive advantage. Journal of Competitiveness, 3(3), 108-118. 
67. Mudabi, R. \& McDowell Mudabi, S. (1995). From Transaction Cost Economics to Relationship Marketing: a Model of Buyer-Supplier Relations. International Business Review, 4(4), 419-433. http://dx.doi.org/10.1016/0969-5931(95)00017-8

68. Nagurney, A. (2010). Optimal supply chain network design and redesign at minimal total cost and with demand satisfaction. International Journal of Production Economics, 128(2), 200208. http://dx.doi.org/10.1016/j.ijpe.2010.07.020

69. Ni, L. (2006). Relationships as organizational resources: Examining public relations impact through its connection with organizational strategies. Public Relations Review, 23(3), 276-281. http://dx.doi.org/10.1016/j.pubrev.2006.05.007

70. Nishiguchi, T. \& Anderson, E. M. (1995). Supplier and Buyer Networks. In E. Bowman, \& B. Kogut (Eds.), Redesigning the firm (65-85). New York, NY: Oxford University Press.

71. Normann, R. (2001). Reframing Business: When the Map Changes the Landscape. Chichester, UK: Wiley.

72. Penrose, E. T. (1959/1995). The Theory of the Growth of the Firm. Oxford, UK: Oxford University Press.

73. Porter, M. E. (1980). Competitive Strategy. New York, NY: The Free Press.

74. Porter, M. E. (1985). Competitive Advantage. New York, NY: The Free Press.

75. Porter, M. E. (1986). Competition in Global Industries. Boston, MA: Harvard Business School Press.

76. Porter, M. E. (1990). The Competitive Advantage of Nations. New York, NY: The Free Press.

77. Powell, W. W. (1990). Neither markets nor hierarchies: Network forms of organizations. In B. M. Staw (Ed.), Research in organizational behavior, 12 (295-336). Greenwich, CT: JAI Press

78. Ring, P. S. \& Van de Ven, A. H. (1992). Structuring cooperative relationships between organizations. Strategic Management Journal, 13(7), 483-498. http://dx.doi.org/10.1002/ smj.4250130702

79. Rust, R. T., Zahorik, A. J. \& Keiningham, T. L. (1995). Return on quality (ROQ): Making service quality financially accountable. Journal of Marketing, 59(2), 58-70. http://dx.doi. org/10.2307/1252073

80. Schumacker, R. E. \& Lomax, R. G. (1996). A Beginner's Guide to Structural Equation Modeling. Mahwah, New Jersey: Lawrence Erlbaum Associates. http://dx.doi.org/10.1080/107055196 09540025

81. Sheth, J. N., Gardner, D. M. \& Garett, D. E. (1988), Marketing Theory: Evolution and Evaluation. New York, NY: John Wiley \& Sons.

82. Sheth, J. N. \& Parvatiyar, A. (1995). The Evolution of Relationship Marketing. International Business Review, 4(4), 397-418. http://dx.doi.org/10.1016/0969-5931(95)00018-6

83. Steenkamp, J.-B. E. M. \& Baumgartner, H. (2000). On the Use of Structural Equation Models for Marketing Modeling. International Journal of Research in Marketing, 17(2-3), 195-202. http://dx.doi.org/10.1016/S0167-8116(00)00016-1

84. Streukens, S., van Hoesel, S. \& de Ruyter, K. (2011). Return on marketing investment in B2B customer relationships: A decision-making and optimization approach. Industrial Marketing Management, 40(1), 149-161. http://dx.doi.org/10.1016/j.indmarman.2010.06.002 
85. Šebo, J. \& Šebová, M. (2010). Meranie konkurencieschopnosti viackriteriálnym hodnotením=Measuring competitiveness using multi-criteria evaluation. Journal of Competitiveness, 2(1), 33-40.

86. Ullman, J. B. (2006). Structural Equation Modeling: Reviewing the Basics and Moving Forward. Journal of Personality Assessment, 87(1), 35-50. http://dx.doi.org/10.1207/ s15327752jpa8701_03

87. Van Auken, S. (2001). Resources and Relationships: New Drivers of Marketing Thought. Journal of Economic and Social Research, 3(1), 29-41.

88. Vargo, S. L. \& Lusch, R. F. (2004). Evolving to a New Dominant Logic for Marketing. Journal of Marketing, 68(1), 1-17. http://dx.doi.org/10.1509/jmkg.68.1.1.24036

89. Veloutsu, C., Saren, M. \& Tzokas, N. (2002). Relationship marketing - What if...? European Journal of Marketing, 36(4), 433-449. http://dx.doi.org/10.1108/03090560210417255

90. Veludo, M. de L., Macbeth, D. \& Purchase, S. (2006). Framework for relationships and networks, Journal of Business \& Industrial Marketing, 21(4), 199-207. http://dx.doi.org/10.1108/ 08858620610672560

91. Williamson, O. E. (1985). The Economic Institutions of Capitalism. New York, NY: The Free Press.

92. Williamson, O. E. (1996). The Mechanisms of Governance. New York, NY: Oxford University Press.

93. Williamson, O. E. (2010a). Transaction cost economics: the origins. Journal of Retailing, 86(3), 227-231. http://dx.doi.org/10.1016/j.jretai.2010.07.006

94. Williamson, O. E. (2010b). Transaction Cost Economics: The Natural Progression. Journal of Retailing, 86(3), 215-226. http://dx.doi.org/10.1016/j.jretai.2010.07.005

95. Wright, P.M., Dunford, B.B. \& Snell, S.A. (2001). Human resources and the resource-based view of the firm. Journal of Management, 27(6), 701-721. http://dx.doi.org/10.1177/014920630 102700607

96. Yang, J., Wang, J., Wong, C. W. Y. \& Lai, K. (2008). Relational stability and alliance performance in supply chain. Omega, 36(4), 600-608. http://dx.doi.org/10.1016/ j.omega.2007.01.008

97. Zaheer, A., McEvily, B. \& Perrone, V. (1998). Does trust matter? Exploring the effects of interorganizational and interpersonal trust on performance. Organization Science, 9(2), 141159. http://dx.doi.org/10.1287/orsc.9.2.141

98. Zich, R. (2010). Koncepce úspěchuschopnosti a její pojetí strategie. E+M Ekonomie a management, 13(1), 60-75. 


\section{Contact information}

Matevそ̌ Rašković, PhD (corresponding author)

University of Ljubljana, Faculty of Economics,

Academic unit for international economics and business

Kardeljeva pl. 17, 1000 Ljubljana, Slovenia

E-mail:mateværaskovic@ef.uni-li.si

*2012-2013 visiting scholar at Shanghai Institute of Foreign Trade, China

*2010-2011 visiting graduate fellow at Harvard University, US A

Maja Makovec Brencič, PhD full professor

University of Ljubljana, Faculty of Economics,

Academic unit for international economics and business

Kardeljeva pl. 17, 1000 Ljubljana, Slovenia 


\section{APPENDIX - QUESTIONNAIRE ITEMS}

All questionnaire items were measured as 7-point Likert-type scales, with the following answer values: 1-completely disagree, 4-neutral (neither disagree, nor agree) and 7-completely agree.

\section{COMPETITIVENESS}

a) The supply chain management system at this TNC unit is an important source of the TNC's competitive advantage.

b) Since becoming a supplier $\mathrm{t}$ this TNC, we have become a more competitive firm.

c) Because our supply relationship with this TNC unit is managed efficiently, both our organization and this TNC unit are more competitive on the market.

2. RELATIONSHIP-BASED INFORMATION (SHARING)

a) We get all the relevant information from this TNC unit and this supports us in defining product and service prices of supplies to this TNC unit.

b) We get all the relevant information from this TNC unit and this supports us in defining product and service quantities of supplies to this TNC unit.

c) We get all the relevant information from this TNC unit and this supports us in logistic operations of supplies to this TNC unit.

d) We get all the relevant information from this TNC unit and this supports us in production processes related to supplies to this TNC unit.

e) We get all the relevant information from this TNC unit and this supports us in foreseeing future actions of this TNC unit.

\section{TRANSACTION-SPECIFIC INVESTMENTS (TSI) IN PEOPLE}

a) We have invested time and effort to learn about the business practices of this TNC unit.

b) Supplying to this TNC unit required additional tasks, training and skills for at least some of our employees.

c) If we stop working with this TNC unit, we would be wasting a lot of knowledge regarding the TNC's method of operation.

\section{TRANSACTION-SPECIFIC INVESTMENTS (TSI) IN PHYSICAL ASSETS}

a) We have made important investments to deliver products to this TNC unit.

b) Our production processes have been tailored to meet the requirements of supplying to this TNC unit.

c) We have made important investments to handle internally the products and services that are ordered by the selected TNC unit.

\section{INTERORGANIZATIONAL TRUST}

a) This TNC unit has always been evenhanded and straightforward in their negotiations with us.

b) Based on past experience, we can with complete confidence rely on this TNC unit to keep promises made to us.

c) This TNC unit is a trustworthy business partner. 


\section{INTERPERSONAL TRUST}

a) My contact person at this TNC unit has always been evenhanded and straightforward in negotiating with me.

b) My contact person at this TNC unit is a trustworthy person.

c) I have faith in my contact person at this TNC unit to look out for our company interests.

7. JOINT PLANNING

a) We plan volume demands for the next season together with this TNC unit.

b) We share our long-term product and service plans with this TNC unit.

c) This TNC unit provides us with sales forecasts for the products we supply to this unit.

8. JOINT PROBLEM SOLVING

a) We and this TNC unit deal with problems that arise in the course of the relationship together.

b) In most aspects of the relationship with this TNC unit, the responsibility for getting things done is shared.

c) We and this TNC unit are committed to improvements that may benefit the relationship as a whole.

9. RELATIONSHIP FLEXIBILITY (7-point scale: 1-very poor, 7-very well)

a) How well does your supply relationship with this TNC unit respond to day-to-day operational changes (with minimal impact on performance)?

b) How well does your supply relationship with this TNC unit respond to occasional (i.e. monthly, quarterly) tactical changes (with minimal impact on performance)?

c) How well does your supply relationship to this TNC unit respond to one-way, long-term strategic changes (with minimal impact on performance)? 